University of Warwick institutional repository: http://go.warwick.ac.uk/wrap This paper is made available online in accordance with publisher policies. Please scroll down to view the document itself. Please refer to the repository record for this item and our policy information available from the repository home page for further information.

To see the final version of this paper please visit the publisher's website. Access to the published version may require a subscription.

Author(s): Peter Marshall

Article Title: Forgery and Miracles in the Reign of Henry VIII

Year of publication: 2003

Link to published version: http://dx.doi.org/10.1093/past/178.1.39

Publisher statement: This is a pre-copy-editing, author-produced PDF of an article accepted for publication in Past and Present following peer review. The definitive publisher-authenticated version Marshall, $P$. (2003). Forgery and Miracles in the Reign of Henry VIII. Past and Present, Vol. 178, pp. 39-73 is available online at:

http://dx.doi.org/10.1093/past/178.1.39 


\title{
FORGERY AND MIRACLES IN THE REIGN OF HENRY VIII*
}

\author{
Peter Marshall, University of Warwick
}

In June 1534, as the final ties connecting the English Church to Rome were inexorably being severed, Archbishop Thomas Cranmer issued an order for the preservation of 'unity and quietness'. For the space of a year, preachers were to steer clear of six topics which 'have caused dissension amongst the subjects of this realm', namely, 'purgatory, honouring of saints, that priests may have wives, that faith only justifieth, to go on pilgrimages, to forge miracles'. ${ }^{1}$ The first four items on this list represent important doctrinal flash-points of the early Reformation; the fifth, an increasingly contentious ingredient of popular religious culture. But the sixth - 'to forge miracles' - is a more puzzling and arcane inclusion, which those scholars noticing the document have generally passed over without comment, or glossed as a reference to miracles in the round. ${ }^{2}$ Starting from this textual loose end, my essay aims to unravel a thread which can be found running the course of the Reformation in Henry VIII’s reign: a persistent concern to identify and accentuate instances of the fraudulent and the counterfeit. ${ }^{3}$ From asking why the idea of 'forged miracles' might have been at the forefront of Cranmer's thinking at this particular juncture, it goes on to consider the broader implications of the theme for understanding profound and long-term shifts in religious and political culture taking place from the 1530s. A significant achievement of recent scholarship has been to reinsert the miraculous as a core element of early modern religious experience, and to insist upon the fundamental lineaments of the 'supernatural universe' inhabited by Catholic and Protestant Europeans alike throughout the sixteenth century and beyond. ${ }^{4}$ But the following 
discussion stands in a somewhat contrapuntal relationship to this approach, aiming to elucidate the development of a particular strain of scepticism, and its connection to a distinct moment of cultural rupture. Close attention to the meanings of 'forgery', I will argue, brings into focus important questions about the intellectual parentage of Henrician religious policy, and about its doctrinal and functional consistency. It also helps us better to comprehend the perplexing fragility exhibited by what Eamon Duffy has termed 'traditional religion' in the early years of the English Reformation. ${ }^{5}$

Public ‘dissension' over forged miracles in the early summer of 1534 may have been largely of the government's own making. A few weeks prior to the issuing of Cranmer's edict, on 20 April 1534, the execution took place at Tyburn of Elizabeth Barton, the Nun or 'Holy Maid' of Kent, a figure once a mere footnote to the historiography of the period, but recently the focus of considerable scholarly interest, emerging as perhaps the most formidable of all Henry’s early opponents. ${ }^{6}$ Barton was a maidservant in a Kent gentry household, who began to experience visions and trances after falling ill in 1525, and was cured of her sickness after a pilgrimage to the image of Our Lady in the chapel of Court-at-Street. Her reputation as a visionary and worker of miracles continued to grow after she became a nun at St Sepulchres in Canterbury, and her revelations (mostly concerning purgatory, confession, and prayer to the saints) were widely publicised by a group of clergy around the Canterbury Benedictine, Edward Bocking. But as the divorce campaign gathered pace, her revelations took a dangerously political turn, and she prophesied that Henry would not remain king for six months if he put aside Queen Catherine. 
Barton's importance for this essay resides in the orchestration of her end, a campaign of denigration channelled primarily through two public narratives: a sermon preached at Paul's Cross, and again at Canterbury, in late 1533, and an act of attainder passed in March 1534. ${ }^{7}$ Both texts relentlessly cast Barton as a fraud and a faker, and are determined to demonstrate, rather than merely assert, the falseness of her claims. Assurances were repeatedly given that she had confessed all to be 'counterfeited and feigned'. In her cell at St Sepulchre's had been found 'brimstone, arcefetida, and other stinking gommes and powders’ for staging dramatic diabolical visitations. Satan had reportedly spat in her face after his advances to her were spurned, and the napkin which wiped the spittle away was presented to her confessor, 'black as soot and as stinking as carrion'. But Barton had simply taken soot 'and mingled it with a stinking thing, you wot what I mean'. Another 'solemn relic', a letter penned for Barton by St Mary Magdalene, was ‘by much inquisition’ traced to a Canterbury monk named Hawkhurst. Barton's veil, scorched by demonic fire, was also ‘shewn as a relic to divers', but 'she was the devil herself which burned the veil'. ${ }^{8}$ Not simply the deluded dupe of conservative forces, Barton was an artful instigator, her spiritual productions premeditated deceits. In the attainder, the words 'feign' and 'feigned' appear no fewer than thirty-seven times, along with much 'hypocrisy', 'craft', and 'dissimulation'.

The imperatives here were candidly admitted. Barton’s trances had brought her into 'marvellous credit' with the people; moreover 'the great grudge and contradiction, which have been made against the lawful and godly marriage [Henry’s to Anne Boleyn]' was said to have been specially grounded upon 'false miracles and revelations'. Now that the falsehood was detected, however, the king's subjects would never again be lured into sedition by such 'false persuasions'. ${ }^{9}$ This was a set of equations pregnant with future possibility. Reinterpreted by the regime’s apologists, 
the life of Elizabeth Barton brought together a number of motifs which were to reemerge with growing insistence over the course of the Henrician Reformation: unverifiable private revelations, mired in dark ulterior motives; false relics, exhibited to the credulous; contrived 'miracles', with entirely naturalistic explanations; pilgrimages to wonder-working images, fostered 'for lucre'. ${ }^{10}$ Barton was an exceptionally dangerous opponent of the king's proceedings because her manipulation of the supernatural order met expectations deeply rooted in contemporary religious culture. ${ }^{11}$ But by the same token, the reshaping of her narratives as exemplary stories of ‘forged miracles’ drew on a range of long-established interpretative possibilities. The remainder of this essay explores where the materials for a plausible counterhagiography based on allegations of fraud may have come from, and shows how by the 1530s they were combining in new ways to suggest possibilites more ambitious than the demonisation of a young Kentish nun.

In the succeeding decades Elizabeth Barton was to become a secure reference-point for popish guile and trickery, one who 'passed all others in devilish devices'. ${ }^{12}$ Yet her exposure in 1533 came as no surprise to the growing minority of English evangelicals, able already to identify her miracles as false by the application of quite independent criteria. By the late 1520s, the discernment of 'true' from 'false' miracles had become a defining issue for the emergent evangelical movement. To William Tyndale, ends not means were what counted; Barton's miracles, like those of the 'Maid of Ipswich' before her, promoted the idolatrous invocation of saints and worshipping of statues, and thus could not be true, a perception shared by other early 
evangelicals such as Thomas Bilney, John Frith, and Robert Barnes: the miracles of wonder-working images were 'but elusyons of $\mathrm{y}^{\mathrm{e}}$ deuil'. ${ }^{13}$ All necessary truths were contained within Holy Writ, and did not require miracles for their verification. However, Scripture was not silent on the subject of false miracles: the confrontation of Moses and Aaron with the sorcerers of Pharaoh (Exod. 7:11) showed God permitting false miracles in order to harden the hearts of the unfaithful. The New Testament contained the false miracle-workers Simon Magus and Elymas (Acts 8:9, 13:7), as well as the words of Christ Himself (Matt. 24:24; Mark 13:22) that false prophets would come displaying 'great signs and wonders'. St Paul's warning (2 Thess. 2:3-12) was yet more explicit: in due course Antichrist ('that man of sin', 'the mystery of iniquity') would confound the unfaithful with 'power and signs and lying wonders'. ${ }^{14}$ Thus, suppositious miracles like the revelations of Barton were not so much ecclesiastical abuses susceptible to reformation, as powerful signifiers in a particular eschatological reading of history. Tyndale detected an increasing tempo of 'Antichrist's lying miracles', deceptions which 'grow daily more and more'. The question of instrumentality, however, could be left conveniently open: miracles either feigned by the clergy for profit and power, or transacted by the devil to confirm false doctrine. $^{15}$

For Tyndale’s leading opponent, true and false miracles performed an equally essential validating function. Much of Sir Thomas More’s 1529 Dialogue Concerning Heresies comprises a commentary on the discernment of miracles; their truth is adduced from the common consent of Christ's Church, the testimony of credible men, and a universal belief among all nations. It was absurd for heretics to insist that the devil could transact them by God's sufferance, but deny that God might perform them himself. ${ }^{16}$ A more doctrinaire restatement followed in More’s Confutation of 
Tyndale’s Answer: miracles were a mark of the true Church, and a striking characteristic of heretics down the ages was that God permitted no miracles to be performed among them. ${ }^{17}$ But this emphasis did not underwrite an indiscriminate credulity. More made a point of stressing how exceptional miracles were, and firmly committed himself to only one of the 'great and undoubted miracles' to have taken place at pilgrimage sites: Anne Wentworth's cure through the intercession of Our Lady of Ipswich. ${ }^{18}$ More's scepticism about Elizabeth Barton is well attested, and of a piece with attitudes from his earlier career. ${ }^{19}$ In a dedicatory epistle of 1506, More airily announced that there was scarcely a saint's life uncorrupted by the insertion of pious falsehoods, a sentiment firmly in line with the view of traditional hagiography taken by his friend Erasmus. ${ }^{20}$ A decade later, he mocked private revelations and the appeal to untrustworthy miracles in his defence of Erasmus against the London Carthusian John Batmanson, despairingly recounting a meeting with a Coventry Franciscan, who had attained local renown by preaching that anyone saying the psalter of the Blessed Virgin every day could not be damned: 'the whole gist of his reasoning was dependent on miracles'. More found it laughable. ${ }^{21}$

By the time he came to write the Dialogue Concerning Heresies, More was noticeably less critical of both religious orders and popular piety, but still the possibility was frankly admitted that miracles might be faked. Three specific cases were cited. The first was a tale More claimed to have heard from his father, of a beggar in Henry VI's reign falsely claiming to be cured of blindness at the shrine of St Alban. ${ }^{22}$ Better known was the notorious Jetzer case of 1507, a cause célèbre involving a group of Bernese Dominicans who had faked appearances of the Virgin to discredit the doctrine of the Immaculate Conception. ${ }^{23}$ His third case revolved around another 'holy maid', Elizabeth of Leominster (Herefordshire), who in the reign of 
Henry VII had been enclosed behind iron grates in the priory rood loft, her only food unconsecrated eucharistic bread, sometimes seen to fly miraculously to her mouth from the paten in the prior's hand. In the end, she confessed to being the prior's lover and it emerged that the host-miracle depended on a device using thin wire. ${ }^{24}$ More had good reason for his apparent candour, however. Far from discrediting miracles, these were the exceptions to prove the rule, manifest instances of the providence of a God who 'always bryngyth suche false myracles to lyght'. ${ }^{25}$

That ostensibly sacred things might be fakes was thus hardly an astonishing revelation to educated Catholics of More's generation. Indeed, it was a trope with a venerable ancestry. By the later middle ages, there were longstanding anxieties on the part of clerical elites about the authenticity of relics in particular, a canon of the Fourth Lateran Council (1215) ordering that pilgrims were not 'to be deceived by lying stories or false documents, as has commonly happened in many places'. ${ }^{26}$ By the fourteenth century, the false pardoner touting forged bulls, relics and miraclestories had become a stock literary character, Langland imagining a rogue pardoner beguiling 'the ignorant folk' with letters of indulgence, and a document 'covered with bishops' seals', before splitting the proceeds with a corrupt parish priest. ${ }^{27}$ His Italian equivalent, Boccacio’s Friar Cipolla, returns from Jerusalem exhibiting ‘a small phial containing some of the sound from the bells of Soloman's temple' as well as 'one of the feathers of the Angel Gabriel' ${ }^{28}$ The pardoner in Chaucer's Canterbury Tales employs a more homely, but no less efficacious relic as his meal-ticket: 'a sholderboon / Which that was of an hooly Jewes sheep', able to cure sick livestock if washed in their drinking-water. ${ }^{29}$ Chaucer's pardoner was at once a caricature and a stereotype, but not an unrecognisable one in early Tudor England. In 1494, and again in 1497, false pardoners were pilloried in London 'ffor gederyng of money by a 
ffayned pardon'. ${ }^{30}$ The satirical genre was going strong into the early 1530s. In the interludes of John Heywood, pardoners proudly display 'the great-toe of the Trinity', 'of All-Hallows, the blessed jaw-bone', 'a buttock-bone of Pentecost', in addition to the now-classic bone of 'a holy Jewes shepe'. ${ }^{31}$ Here we are returned to the milieu of Thomas More, Heywood's patron and uncle by marriage. In More’s Dialogue, the scandal of fraudulent relics is an argument allowed to the interlocutor known as 'the Messenger': reverence is often paid 'to some olde rotten bone that was happely some tyme as Chaucer sayth a bone of some holy Iewes shepe... some one sayntes hed is shewed in .iii. places. And some one hole sayntes body lyeth in dyuers countreys' ${ }^{32}$ In making these objections, the Messenger shows himself not so much a follower of Luther, as of Erasmus. The Dutch humanist's scorn for the relic trade was well-known to educated opinion throughout Europe, and his sharpest strictures on the topic, importantly for our purposes, have a conspicuously English setting. The 1526 colloquy Peregrinatio religionis ergo (A Pilgrimage for Religion's Sake) is a thinly fictionalised account of visits to Walsingham and Canterbury in 1512-14, and a corrosive satire on the greed of those administering the shrines and the credulity of the worshippers. Targets include foolish beliefs about statues smiling and inclining their heads, and about letters from the Virgin delivered by angels ('to prevent suspicion of fraud, you shall see the very autograph’). At Walsingham, Erasmus was scornful of miracle claims: a mounted knight who had been able to gallop through a tiny gateway into the enclosure to escape his enemies, a structure housing two wonder-working wells miraculously transported there ages before. Erasmus thought the house didn't look very old, and was pointed to a mouldy bear-skin as proof of antiquity. The shrine’s premier relic, a crystal vessel containing milk of the Virgin, fared no better at his hands. Just as Christendom had enough surviving fragments of the true cross to 
provide 'a full load for a freighter', so it was remarkable that a woman with only one child could have produced so much milk. The relic, he slyly suggested, seemed like 'powdered chalk, tempered with white of egg'. ${ }^{33}$ By contrast, it could hardly be doubted that St Thomas Becket's bones were actually housed at Canterbury. Erasmus was shown the martyr's skull: 'the top of the cranium is bared for kissing, the rest covered with silver'. Yet here too sharp practice is detected: an almshouse on the London road, from which the inmates waylay travellers with a relic purporting to be St Thomas's shoe; the monks' collection of linen rags, with which 'they say, the holy man wiped the sweat from his face or neck, the dirt from his nose'. While Erasmus seems to have been prepared gamely to play along at Canterbury, his companion John Colet was repelled, shrinking from kissing an arm with flesh still attached, and refusing one of the fluid-stained rags as a gift. ${ }^{34}$ At both of England's leading pilgrimage sites, humanist piety and scholarship were deeply affronted by the superfluous wealth, the superstitious veneration of the relics, and, perhaps most of all, by the absence of reliable verification of their authenticity.

'Forged miracles' and 'feigned relics' were then in no sense a discovery of the early Reformation, but a medieval cliché, invested with greater moral purpose in the early sixteenth century by the strictures of Christian humanism. By the early 1530s two distinct approaches were crystallising: a broadly ‘Erasmian’ Catholic position which looked to eradicate such abuses through vigilant oversight and sound scholarship, and an evangelical, ‘apocalyptic’ stance which identified fraudulent miracles with the false wonders of Antichrist. The latter had an alternative medieval tradition it could draw on here, a fierce Lollard critique of saint-cults which

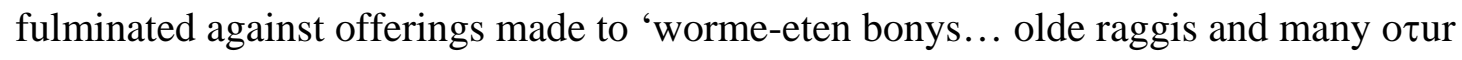

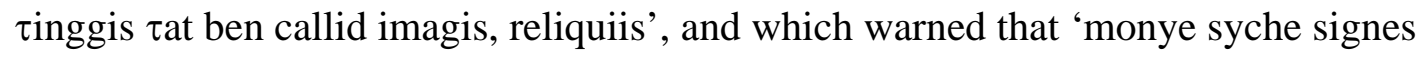




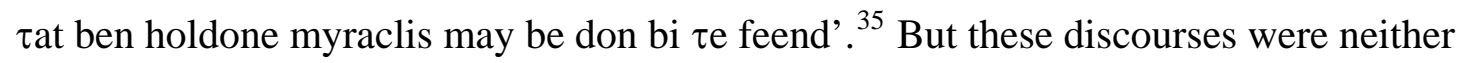
unconnected nor intrinsically incompatible. The assertion of an early sixteenthcentury Salisbury Lollard, that 'among the reliques that be worshipped in churches is many a shippes bone', was close to being a Chaucerian/Erasmian truism, tolerated in other contexts, and when Tyndale alleged saints' lives to be corrupted with 'lies and feigned miracles', he was reiterating a point Erasmus and More had long since conceded. ${ }^{36}$ Indeed, Tyndale may have been the translator of the first English edition of Erasmus's best-seller, the Handbook of a Christian Knight, a work which condemns those rejoicing in possessing 'a lytell pece of the crosse', or having in greater reverence the ashes or bones of Paul than his ‘quycke ymage’ speaking through his writings. 'Let the vnfaythfull meruayle at these myracles and sygnes for whome they be wrought'. ${ }^{37}$

III

By mid-1534, attention to the clergy’s ability 'to forge miracles' had been sharply concentrated by the war of books between More and his evangelical opponents, and by the requirements of disparaging the Nun of Kent. From the following year, however, the theme began to play a greater, at times pivotal role in the execution of government policy. The catalyst was the campaign against the monasteries, principal repositories of relics and sites of miracle-generating shrines. An injunction carried by the visitors inspecting religious houses in 1535 was that monks 'shall not show any relics or feigned miracles for increase of lucre'. ${ }^{38}$ While the frequent allegations about false relics in the reports of the monastic visitors have long been noted by historians 
of the dissolution, there has been little attempt to identify their antecedents or assess their potency as an aspect of anti-monastic propaganda. ${ }^{39}$

Despite a reputation as unprincipled thugs, the visitors appointed by Thomas Cromwell - Richard Layton, Thomas Legh, John Ap Rice, John Tregonwell - were intelligent and educated men, their interim reports to the minister often witty, cruel, and politically astute. ${ }^{40}$ In August 1535, Layton despatched from Bath 'a bowke of Our Lades miracles, well able to mach the Canterberie talles', and reported that at Farley, a cell of Lewes priory, he had confiscated 'vincula Sancti Petri' [the chains of St Peter] which women placed round themselves during childbirth. Significantly, he charged the monks with 'haveyng therof no writyng', and a similar inability to 'tell howe they came by’ combs of Mary Magdalen, St Dorothy and St Margaret. ${ }^{41}$ From Bristol Layton promised to send the relics he had gathered at Maiden Bradley Priory, 'wherein ye shall se straingeis thynges'. These included 'Godes cote, Oure Lades smoke, parte of Godes supper', as well as the stone on which Jesus was born: 'belyke ther is in Bethelem plentie of stones \& sum qwarrie \& makith ther maingierres off stone'. ${ }^{42}$ At Bury St Edmunds John Ap Rice found 'moche vanitie and superstition, as the coles that Saint Laurence was tosted withall, the paring of S. Edmundes naylles, S. Thomas of Canterbury penneknyff \& his bootes’, and (invoking a familiar Erasmian trope) 'peces of the holie crosse able to make a hole crosse of' ${ }^{43}$ The summary of the reports of the Northern and East Anglian visitations, known as the Compendium Compertorum, noted dozens of cases of 'superstition', including numerous saints' girdles to assist the safe delivery of children, at least seven specimens of the Virgin's milk, and ten pieces of the true cross. The spurious character of sacred objects and the uncertainty of their origins is often remarked. The summary judgement on Bury St Edmunds was of many 'vain and fictitious relics', 
and on Walsingham, 'much superstition in feigned relics and miracles'. ${ }^{44}$ Relics removed from churches in 1535 included a portion of Our Lady’s milk from St Pauls 'which was broken and founde but a peece of chalke', one of many 'used for covetousness in deceaphing the people. ${ }^{, 45}$

The Virgin’s milk in fact supplies the clearest evidence of insistent probing around issues of authentication. In 1535 articles issued for Walsingham Priory relentlessly grilled the Augustinians about practices at the shrine. Which relics were most esteemed and 'what probacion or argument have they to shewe that the same are trewe reliques'? 'What is the gretest miracle and moste undoubted whiche is said to have ben doon by Our Ladye here, or by any of the said reliques?' The canons were demanded whether proper depositions had been taken from witnesses, and admonished 'whether they knowe not that men shulde not be light of credite to miracles, unlesse they be manifestly and invinciblie proved'. There was a particular concern with the principal Marian relic: 'Item, whether Our Ladys milke be liquid or no?' The former sexton was to be asked whether he had renewed the relic when it seemed likely to dry up, and whether he had 'invented any relique for thaugmentacon of his prouffet'. The articles owed a clear debt to Erasmus’s account of Walsingham in the Peregrinatio. In addition to their concern with the viscosity of the milk, they asked about other objects of Erasmus's derision: the antiquity of the house over the wells, the bear-skin, the miracle of the knight. An article about the holding up of boards to shame pilgrims into making offerings also seems to be modelled on Erasmus's comments about practices at Walsingham and other European shrines. ${ }^{46}$ It would appear that the withering contempt of radical Erasmianian, rather than the theological resolve of early Protestantism, was the ideological face of the dissolution in its first phase. 
In the event, 'superstition' was not a primary public justification for the parliamentary dissolution of the lesser monasteries in the spring of 1536 . The government had, for the moment at least, decided to preserve the larger houses where many relics were housed. But the drafting of a bill 'agaynst pilgrimages and superstitious worshippinge of reliques’ suggests the range of policies being considered at this time. It prescribed immediate expulsion for religious who 'for lucre sett furthe their images or reliques' and allure people 'to rune abowte on pylgrymage' to them. ${ }^{47}$ The visitation had certainly garnered evidence to condone further action along these lines. In June 1536 Bishop Hugh Latimer preached to convocation attacking 'false miracles', and the 'pig's bones' often taken for saints' relics. There were 'plenty of such juggling deceits', as yet unredressed. ${ }^{48}$ The royal injunctions issued in August instructed curates not to 'set forth or extol any images, relics, or miracles for any superstition or lucre'. ${ }^{49}$ And in the following year the government openly co-opted the international authority on bogus relics, sponsoring or permitting the publication in English translation of the Peregrinatio religionis ergo ${ }^{50}$ The (anonymous) translator’s preface attacks the ‘counterfayting’ involved in Palm Sunday ceremonies at Jerusalem and Compostella, though more pernicious were those 'that setforthe uncertayn relyques for certayne'. Erasmus earns praise for exposing the superstitious worship of 'bones, heades, iawes, armes, cotes, cappes, hattes, shoes, mytres, slyppers, sadles, rynges, bedes, gyrdles, bolles, belles, noses, gloves, toyes, taperes, candelles, bootes, sporres' - a rhythmic litany evocative of the derisive lists of the monastic visitors. ${ }^{51}$ In the text itself, a sceptical comment of 'Menedemus' on the Walsingham relics - ‘multa talia fingantur ad quaestum' - is translated as ‘that many of thes be faynyd for lukre', the very phrase used in the monastic visitation injunctions of $1535 .^{52}$ 'Feigning for lucre' was a trope employed to devastating effect 
over the next couple of years to help bring down the remainder of England's monasteries, and with them the whole apparatus of shrines and pilgrimage.

The exposure of forged miracles and feigned relics reached a climacteric in the early months of 1538. In February, the commissioners suppressing the Cistercian monastery of Boxley in Kent, site of a famous crucifix called 'the Rood of Grace', discovered 'certen Ingynes \& old wyer wyth olde Roton stykkes in the backe of the same that dyd cause the eyes of the same to move \& stere in the head therof lyke unto a lyvelye thyng'. The Rood was exhibited in Maidstone to let the people see 'the false, crafty \& suttel handelyng', and was subsequently paraded at court, where Henry reportedly hardly knew 'whether more to rejoice at the exposure or to grieve at the long deception'. ${ }^{53}$ On 24 February the bishop of Rochester, John Hilsey, displayed the 'idolatrie and crafte' of the rood at Paul's Cross, pronouncing that the monks 'had gotten great riches in deceavinge the people'. ${ }^{54}$ The case was an instant cause célèbre, reformers on the continent excitedly reporting that 'the imposture of the priests is made known to every one'. ${ }^{55}$ But more conservative English chroniclers also recorded the 'slayghtes and false inv[entions] that were fownde in the same' ${ }^{56}$ Hilsey combined his exposure of the Rood with shocking claims about another of England's pilgrimage centres. The Holy Blood of Christ venerated at the abbey of Hailes in Gloucestershire was 'but a duckes blood'. ${ }^{57}$ In October, a commission headed by Bishop Latimer impounded the relic, concluding that it was an amber-coloured gum which appeared red when placed in the glass reliquary. ${ }^{58}$ Towards the end of November Hilsey reappeared at Paul's Cross, displaying the relic 'so that every person might well perceive the abuse of the sayd thinge'. He retracted the duck's blood story, and delivered the considered verdict that it was 'hony clarified and coloured with saffron'. 59 
Alongside Elizabeth Barton, the Rood of Boxley and Blood of Hailes were to acquire emblematic status as paradigms of popish deceit. ${ }^{60}$ But they by no means exhausted the potential for uncovering forgery in miracles and relics. In March 1538 Bishop Barlow of St Davids chanced upon a ‘develish delusyon’ called ‘our ladyes taper of Cardigan', a candle believed to have burned for years without being consumed, but which turned out to be partly made of wood. The parish clergy were issued with injunctions to expound to the people the 'disceatfull iugglinge of their predicessours there'. ${ }^{61}$ In the same month, Cromwell 'rejoiced not a little' to hear a relic in Calais identified as a 'sheep's tail'. ${ }^{62}$ Through the summer, confiscation and disposal of suspect relics continued apace. At Wisborough Green in Sussex the churchwardens surrendered an extraordinary collection of 'faynyd \& superstytius relyckes' including milk of the Virgin, relics of the tomb and vestments of St Thomas Becket, of the hair shirt and bones of St James, of the beard of St Peter, and the stones with which Stephen was martyred. ${ }^{63}$ From the Welsh Marches, Richard Ingworth told Cromwell he had acquired 'Malkows ere that Peter strake of' and a thousand 'as trewe as that'. In a passage that might have been lifted from a Heywood interlude, he went on to say that he was sending 'the holyest relyke in all northe Walys', worth twenty marks a year to the friars of Bangor: 'ther may no man kysse yt but he muste knele so sone as he se yt, thowgh yt war in the fowleest place in all the contre, \& he must kys every stone, for in eche ys gret pardon. ${ }^{64}$ Meanwhile in Oxfordshire, John London was suppressing the shrine of Our Lady of Caversham, and confiscating 'many prety relykes’ such as ‘the holy dager that kylled kinge Henry and the holy knyfe that kylled seynte Edwarde'. He had missed nothing 'butt oonly a peece of the holy halter Judas wass hangyd withall'. He subsequently discovered the canons had smuggled away what he grandly termed 'the principall relik of idolytrie within thys realm', an 
angel with one wing that had brought to Caversham the spearhead that pierced Jesus on the cross. ${ }^{65}$ Taking the surrender of the Grey Friars of Reading, London compiled an inventory of their relics beginning with 'twoo peces of the holye crosse' and concluding with 'a multitude of small bonys, laces, stonys, \& armys, wich wolde occupie iiij. schetes of papyr to make particularly an inventary of every part' ${ }^{66}$ Back in Oxford at the end of the year, London told Cromwell that he had collected two heads of St Ursula, but would hang on to them 'tyll I have another hedd of herse', a sardonically Erasmian touch. ${ }^{67} \mathrm{~A}$ few weeks later, he scribbled a sarcastic codicil on the inventory of relics at Coventry Cathedral Priory: 'among thees reliques your lordeshipp shall fynde a piece of the most holy iawe bone of the asse that kyllyd Abell, with divers like'. (An echo of Chaucer's bone of a 'hooly Jewes sheep'?) ${ }^{68}$ It is unlikely that such objects were always the centre of a vibrant popular cult. Reading's relic collection, for example, seems to have been substantially complete before the end of the twelfth century. Moreover, as Ronald Finucane has argued, there seems to be a later medieval shift in the main focus of popular devotion away from saints’ relics to shrines and images with a primarily Marian or Christocentric theme. ${ }^{69}$ Yet the monasteries' continued possession of old, extensive and inauthenticable collections of 'roten bones that be called reliques' made them highly vulnerable to charges of profiteering and idolatry. ${ }^{70}$

A cult still thriving into the 1530s was that of Thomas Becket at Canterbury. There were powerful political imperatives behind the denigration of Becket, papal martyr for the independence of the Church; significant therefore that charges of forgery were prominent at this, perhaps the best historically authenticated of all England's major shrines. In August 1538 Cranmer wrote to Cromwell that he suspected the relic of Becket's blood in Canterbury to be 'but a feigned thing and 
made of some red ochre or like matter', and requested a royal commission to examine it. $^{71}$ For the suppression of the shrine itself in September we rely on the chronicler Charles Wriothesley, who reported that Becket's bones were burned on Cromwell's orders, and that in the process the commissioners 'found his head hole with the bones'. The monks had enclosed another skull in silver for people to offer to, 'so that nowe the abuse was openly knowne' ${ }^{72}$ Erasmus, who had venerated the laminated skull a quarter-century earlier, would probably not have been surprised. At

Canterbury more than elsewhere, the government needed to show the very impulse to venerate the relics to be grounded on fiction and lies. A proclamation of November 1538 struck Becket’s name from the calendar, and insisted that there was nothing in his life 'whereby he should be called a saint, but rather esteemed to have been a rebel and traitor'. ${ }^{73}$ Hagiographies of Becket were thus epitomes of Tyndale’s 'legends corrupt with lies', and one of the charges leading to the execution of the abbot of Glastonbury in 1539 was that he possessed a 'counterfit lyfe' of Becket. ${ }^{74}$ Reformers petitioned that the 'feyned story of his death' be removed from stained glass windows, and in 1543 Cranmer asked convocation to ensure that Becket's name, with all other 'apocryphas, feigned legends', was thoroughly excised from service books. ${ }^{75}$

At the end of September 1538, a new set of royal injunctions provided post hoc justification for the destructive work of a long busy summer. The 1536 warning against extolling images, relics and miracles was now glossed to specify 'feigned images... abused with pilgrimages', 'feigned relics', suffered for the sake of avarice. ${ }^{76}$ In this spirit, the evangelical bishop of Salisbury, Nicholas Shaxton, issued his own injunctions condemning the 'intolerable superstition' caused by 'stinking boots, mucky combs, ragged rochets, rotten girdles, pyld purses, great bullocks’ horns, locks of hair, and filthy rags, gobbetts of wood, under the name of parcels of 
the holy cross'. Shaxton understood that the requirement to provide trustworthy verification represented an unanswerable challenge, the channel through which a radical agenda could proceed under the guise of judicious and reasonable reform. He ordered that all 'relics' be brought to his house at Ramsbury together with supporting documentation. He and his council would examine them, 'and those that be esteemed and judged to be undoubtedly true relics, ye shall not fail at convenable times to have again’. It is safe to assume that Shaxton did not expect to issue many, if any such permissions. $^{77}$

While the visitors and commissioners went about their business in the late 1530s, a flood of official and unofficial propaganda took up the theme of forgery and feigning. In the aftermath of the Pilgrimage of Grace, the Yorkshire gentleman Wilfrid Holme composed an epic poem devoting several stanzas to the papists’ 'girdles invented, and their faire hayres died, / with their chaulke oled for the milke of our Lady'. ${ }^{78}$ In 1538 Nicholas Wyse attacked the 'furred hodes' who mocked the people with feigned miracles, claiming to know personally of a rood in a house of friars who 'have made the people to beleve \& thynke that the heare of his heed \& berde dyd grow.' An image would typically have 'some old wrytten table by it, contaynyng ther in an abhomynable lye, and a false fayned myracle or twayne'. But for sure 'the box to receyve offrynge monye' was not far off. Wyse was another who had read his Erasmus, and recycled a sarcastic trope from the Peregrinatio: it was surprising a strong box was necessary, that the image did not strike down anyone attempting to pilfer the offerings. ${ }^{79}$ Also appearing in 1538 was a translation of Heinrich Bullinger's commentary on 2 Thessalonians, which helpfully substituted for Bullinger’s ‘dyvers pylgremages of hys owne contrye... these of our olde acquayntance'; a list including the Virgins of Wilsdon, Ipswich and Walsingham, the 
Rood of Grace, Canterbury, all with 'more testymonyes of myrackles, the[n] a great navye of shyppes coulde carye awaye’. A now-familiar litany was invoked: images which moved, spoke or sprouted beards, stinking bones of wicked men set forth to be worshiped, 'the fayned myracles of the holy maydens of Kent \& Ipswich’. This text went beyond the mocking tones of Erasmianism to reiterate themes evangelicals had been rehearsing for a decade and more. 'Fayned myracles', and the wax votives and crutches hung up at healing shrines, were the 'false sygnes' of Antichrist. Where Thomas More had seen the exposure of the Berne Dominicans as a guarantee of authentic miracles, here it represented an unmistakable disclosure of the 'mysterye of iniquyte... to the derogacion \& shame of all other false myracles' ${ }^{80}$ The Fantasie of Idolatrie, a ballad composed by Cromwell's client William Gray in 1538-9, supplied a veritable gazeteer of 'fayned myracles and lyes': the 'jugling casts' practised at the shrine of St Erth in Cornwall; the Rood of Ramsbury (Wiltshire), supposedly immovable by sixteen oxen, but taken down by a single man; the Blood of Hailes, now 'knowen to be / But the bloud of a ducke'. Here too the tone was evangelical, the devil able 'to worke ryght wonderful thinges'. ${ }^{81}$

The most complete apologia for the government's actions, and the most clearly official in provenance, was 'A sumarie declaration of the feith uses and observacions in England', composed in 1539 for the benefit of an overseas audience. ${ }^{82}$ Forgery is a recurrent theme. There is confirmation that the skull venerated at Canterbury was 'but a feyned fiction', and of the falseness of Barton's revelations and 'letters from St Mary Magdalen'. The image of Our Lady of Worcester, stripped of her ornaments, was found to be ‘the symilitude of a bishop'. At Boxley 'and sundry other places', monks had manipulated images with 'certain keys \& stringes'. Relics were 'for the most part but feyned thinges', Christ's blood in some 
places 'a pece of redd sylk enclosed in a thyk glasse of Chrystallyn', elsewhere 'oyle colored of sanguinis Drachonis', the milk of Our Lady 'a pece of chalk'. There were 'other innumerable illusions, supersticions and apparent deceiptes, and more of the holy crosse then three waines maye carry'. ${ }^{83}$ The detection of forgery evidently played an important role in the regime's attempts to justify itself to the outside world. In November 1538, Henry's ambassadors in the Netherlands were confronted by a nobleman angry about events in England, and 'declared in suche wise the religion of your Maiestie, the abuses of Cannterbury, Boxley and other places, that he seamed moche to reioyse of thone, and to detest thother' ${ }^{84}$

The 1539 declaration lacked the apocalyptic dimension of more overtly evangelical works, but supplied in its place an emphasis on Henry’s role as abusefinder general, an idea to which evangelicals were often prepared to pay fulsome tribute. In a panegyric published in 1540, John Pylbarough rejoiced that God had raised up Henry to overthrow 'supersticions, counterfeite religion, feyned relyques', and to abolish 'Peters dissimuled successours counterfayte gospell'. ${ }^{85}$ Thomas Becon likewise rejoiced that the fall of false religion 'hath God brought to pass by his dearlybeloved servant, Henry' ${ }^{86}$ The fullest treatment is in William Thomas's Peregrine (The Pilgrim), a tract composed at the end of the reign purporting to be a true account of conversations with some gentlemen in Bologna. The latter regard Henry as the tyrant who spoiled shrines of saints and overthrew the monasteries, but Thomas ripostes with the abuses and frauds his reforms have uncovered. Inventively elaborated accounts of the deceptions at Canterbury, Boxley and Hailes are supplied, though there had been miracles 'thousands as true as this'. To bring an end to 'the falsehood of these jugglers' the king despatched commissioners, first to examine, and then close the religious houses. ${ }^{87}$ 
Henry’s pivotal role here was not just ascribed, but enthusiastically assumed. The royal commission for the closure of St Hugh's shrine at Lincoln in June 1540 made reference to 'dyverse feuyned reliquys and juellys wherewith all the simple people be moche deceyvyd' ${ }^{88}$ During his northern progress in autumn 1541 , Henry was appalled to find shrines and shrine-coverings still standing, despite his orders that 'all such writings and monuments of feigned miracles' were to have been taken away. ${ }^{89}$ In the self-congratulatory preface Henry supplied for the King's Book in 1543 the purging and cleansing of the realm from 'hypocrisy and superstition' looms large among royal achievements. ${ }^{90}$

The motif of the feigned miracle was thus no mere decorative accompaniment to the progress of the Henrician Reformation, but a valuable hermeneutic prism through which the regime's policies could be refracted to appear in the best possible light. The motif was a compound and flexible one. Evangelicals found in the exposure of monkish frauds an inspiration in their cosmic struggle against Antichrist, and a confirmation of the prophetic models of Church history their theorists were starting to formulate. ${ }^{91}$ But the concept could equally seem formally free of any real doctrinal implications. Traditionalists could hardly protest against the exposure of forgery and fraud, and several of the crown's leading agents in the campaign to expose feigned miracles and relics, men like John London and Thomas Wriothesley, had little sympathy for the evangelical cause. ${ }^{92}$ Even the resolutely conservative prelate Stephen Gardiner reportedly said in September 1538 that 'he misliked not the doing at Canterbury'. ${ }^{93}$ Another religious conservative, the humanist Sir Thomas Elyot, assured Cromwell that there was no man living who detested as much as he did 'vayne supersticions, superfluouse ceremonyes, sklaunderouse iouglynges, countrefaite mirakles'.94 
From the outset, two complementary pressures acted to maximise the scope of the 'forged miracle' theme: the determination of evangelicals to conflate specific instances of fraud with a more general critique of traditional religion, and the extent to which almost all assertions of supernatural power seemed to come from opponents of government policy. Elizabeth Barton was not the only individual to disavow Henry’s actions in visions and revelations. A Cistercian of Jervaulx, George Lazenby, was executed in August 1535 after seeking to 'establishe his treason with revelations' from Our Lady and St Anne. ${ }^{95}$ A few years later, a priest in Calais was reported to have denied the king's title, and to have shown a fellow-priest 'divers fond \& folysh visions'. ${ }^{96}$ In 1534-5, as Henry's wrath fell upon the most obdurate of England's monks, the Carthusians, stories of charterhouse visions began to emerge. In the summer of 1534, there were unspecified reports about a brother of Mountgrace: 'I pray god that his revelations may prove better than the maid of kent' ${ }^{97}$ More details were forthcoming from the London Charterhouse, where the sexton had enjoyed a vision of the recently-deceased Prior John Batmanson (he whom More had lambasted for appealing to private revelations against Erasmus) kneeling before the Trinity and interceding for the order. The brethren's fine habits were to be changed for cheap blanket cloth, and they should eat from wooden not pewter plates. These were hardly seditious messages, and the vision itself was old news (Batmanson died in 1531). But in 1534 the authorities took notice, particularly since a potentially feigned 'relic' was involved, a little piece of cloth 'sent from heven by some angell' ${ }^{98}$ In June 1535, 
another London Carthusian confessed to receiving visitations from a deceased brother, urging him to follow the example of their executed prior, John Houghton, a 'marter in hevyn next unto angelles' alongside the recently beheaded Bishop John Fisher. ${ }^{99}$ This was particularly alarming in view of rumours circulating in London that Fisher’s head had been miraculously preserved from corruption when it was put on public display. ${ }^{100}$ Like relics, apparitions of the dead constituted a category where Erasmian and evangelical reforming instincts overlapped. Erasmus had scorned tales about 'ghosts, spectres, phantoms and the dead', which served mainly to make profit for preachers and demagogues. ${ }^{101}$ For evangelicals who rejected the existence of purgatory, all stories of ghosts and apparitions were by definition feigned. The souls departed, observed Robert Wisdom, 'do not come again and play boo peape with us'. 102

Tolerance in court circles towards messages from beyond the grave cannot have been increased by rumours circulating in Dover in 1536 that the candles around the sepulchre of Katherine of Aragon had spontaneously ignited the day before the execution of Anne Boleyn, or in Salisbury in 1538 that the ghost of Jane Seymour had appeared to the king and desired him to go on pilgrimage to St Michael's Mount. ${ }^{103}$ Pilgrimage was also the object of the Suffolk rector, Robert Creukehorne, brought before Archbishop Cranmer and Bishops Shaxton and Latimer in March 1536 over a vision in which the Virgin urged him to preach 'that she wold be honorid at Eppiswhiche and at Willisdon as she hath bee in old tymes'. ${ }^{104}$ In January 1540, a woman from Wells on the Norfolk coast was placed in the stocks for claiming the image of Our Lady of Walsingham had worked a miracle after being brought to London for destruction. ${ }^{105}$ In May 1538, after the pulling-down of the miracleworking rood of St Margaret Pattens in London, fire broke out and ravaged the 
neighbourhood: conservative opinion in the capital discerned divine judgement. ${ }^{106}$ Such interpretations had an alarming capacity to circulate. At St Germans on the south coast of Cornwall, a priest rashly opined that all knew 'what folowed thereof' when the St Margaret Pattens rood was demolished. ${ }^{107}$ By the later 1530s almost any linking of miracles with images or roods had become unacceptable. Cromwell’s postbag in 1538-9 included denunciations of the vicar of Highley, Shropshire, for new-gilding an image said to have restored sight to a blind woman; the vicar of Ticehurst, Sussex, for recounting a miracle of St Martin, and urging parishioners to offer candles to St Loy for their horses and St Anthony for their cattle; and a priest in Ashford, Kent, for preserving an 'erronyous tabull' next to a rood. ${ }^{108}$

In the contest over the royal supremacy and royal policies of reform, the miraculous weighed in one side of the balance only; perhaps because in times of crisis invocations of forces beyond all earthly power are intrinsically more appealing to marginalised and oppositional groups. ${ }^{109}$ Rather than miracles or visions, the crown's supporters preferred to adduce the 'sundry old authentic histories and chronicles', which according to the 1533 Act of Appeals proved England to be an empire, and which contrasted with the forged 'donation of Constantine' used to support papal claims to universal jurisdiction. ${ }^{110}$ There were occasional suggestions of providential occurences revealing God's blessing on the king’s purposes, but this genre looks underdeveloped in the 1530s and 40s. ${ }^{111}$ A distinct nervousness, if not downright suspicion towards all claims to private and supernatural revelation is an almost defining characteristic of 'Henrician’ religion in its official manifestation. ${ }^{112}$

If political pressures were pushing to collapse into one another the categories of the 'miraculous' and the 'feigned', evangelical polemic was working hard to show how particular examples of religious fraud revealed the broader pattern of a popish 
religion whose 'falseness' was not simply error, but a pathological predisposition to lying and deceit. The doctrine of purgatory, which Duffy terms 'the defining doctrine of late medieval Catholicism', was repeatedly said to have been 'feigned to purge thy purse'. ${ }^{113}$ Clerical celibacy was 'feigned chastity'; the apparent holiness of the clergy, 'fayned godlynes falsly pretendynge' ${ }^{114}$ Papist mistranslations of scripture were 'feigned words', 'juggling terms'. ${ }^{115}$ This was a grammar of defamation springing naturally from evangelical lips. Reformers in St Albans complained of the 'crafty juggling' of local conservative priests; the curate of Lenham, Kent, called the chrismatory 'a juggling box'; John Younge of Rye was reported to have said 'that the mass was of a juggler's making, and a juggling cast it was'. ${ }^{116}$ The language of feigning in relation to the eucharist was without doubt its most sensitive application; throughout Henry’s reign evangelicals might go to the stake for denying the real presence of Christ. Nonetheless, evangelical writers ridiculed the traditional proposition that transubstantiation was a miraculous event, and did not hesitate to subsume the mass itself into the capacious category of the 'false miracle'. ${ }^{117}$ It was the very nature of transubstantiation to deceive the senses and make itself understood by the unseeing eye of faith: in the characteristic eucharistic miracle of the later middle ages, the sceptic is confounded by the appearance of the host turned bloody flesh. ${ }^{118}$ To evangelicals, all such 'miracles' were by definition false, and they could hardly have hoped for a better demonstration of how fraud, miracles, and oldfashioned eucharistic piety belonged together than the penitential appearance in February 1545 of a priest at Paul's Cross ‘for fayninge and counterfeyting a miracle’, pricking his finger during mass to make it seem that the host itself had bled. ${ }^{119}$

To speak of the mass as a species of 'juggling' was the rhetoric of an avantgarde, but its cadences inflected offical pronouncements in ways that went beyond the 
exposure of 'fraud' in images and relics. The surrender documents drafted for religious houses in 1538-9 sometimes proclaimed release from 'our pretended religion', 'feigned dissimulation'. ${ }^{120}$ An exhortation read in churches in 1543 attacked the 'counterfaite pardons' with which people had formerly been abused. ${ }^{121}$ There is an echo too in the 1541 proclamation outlawing 'superstitious and childish observations' customarily observed on the Feast of St Nicholas, when children were 'strangely decked and appareled to counterfeit priests, bishops, and women'. ${ }^{122}$ 'Counterfeit' in these contexts is a revealing word. It might signify simply a representation or likeness, but it usually connoted spurious imitation or deceit, a tension at the heart of some contemporary anxieties about all forms of religious imagery. ${ }^{123}$ It also implied, then as now, particular reference to some forms of secular material reproduction, especially of coins and documents, and here I want to suggest a final set of resonances and connections.

The Reformation parliament which sanctioned the attack on the monasteries addressed itself to a range of fraudulent practices rather different from that of which the monks stood accused. A 1530 statute banishing 'outlandish people calling themselves Egyptians' referred to the 'crafte and subtyltie' they used to defraud people in fortune-telling, while the vagrancy act of the following year, in addition to attacking pardoners lacking 'suffycyent authoryte', prescribed whipping for idle persons putting on 'subtyle craftye \& unlawfull games \& playes', or 'feynyng themselfes to have knowledge in physyke, physnamye, palmestrye'. ${ }^{124}$ In the industrial sphere, action was taken in 1532-4 against pewterers employing 'unlawful 
and diseyvable weightes'; dyers using 'a false sleygthie \& deceyvable waye in dyeng'; tanners whose work was 'deceyvably tanned'. A little later there followed an act 'to avoyde the sleyghtye and false making of pynnes'. ${ }^{125}$ Economic regulation of this kind was neither new nor overtly connected to the religious policies of the regime. ${ }^{126}$ But there are conspicuous correspondences here to the language employed by reformers to castigate traditional piety. The importance of things being what they seemed found further expression in the 1533 revival of sumptuary legislation, concerned to avoid 'the subvercion of good and politike ordre in knowelege and distinccion of people according to their estates'. ${ }^{127}$ There were matters too of direct and immediate affront to the king's majesty. Counterfeiting the king's coin, and forging his great or privy seals were offences under the treason act of 1351. But in 1536 a new law made it high treason to counterfeit the royal sign manual or privy signet, under the terms of which a clutch of offenders were executed at Tyburn over the next few years. ${ }^{128}$ In 1534 'counterfettors of any coin' headed the list of offenders in the Marches of Wales henceforth to be tried in royal courts. ${ }^{129}$ Here, at the crux of the Henrician Reformation, we encounter (unsurprisingly perhaps) a heightened concern about symbolic representations of royal authority. ${ }^{130}$

The instinct to equate symbols of royal and divine dominion came naturally to contemporaries. In the fifteenth century, Archbishop Arundel defended the worship of images by analogy with the doffing of caps accorded to letters sent by kings and lords 'ensealed with their arms or with their privy signet'. ${ }^{131}$ Thomas More drew on a similar equivalence in formulating a sanguine response to the charge that the Church might erroneously canonise ‘untrewe men'. It was right to offer hospitality to all who came into one's country wearing the king's badge, even if among them were spies or enemies of the king. ${ }^{132}$ Evangelical writers employed the metaphor of the king's seals 
and arms not in connection with images or saints, but as an analogue of the sacraments, unimpeachable tokens of an unseen sovereign power. ${ }^{133}$ Yet they also understood that the vulnerability as well as the inviolability of royal symbols was a reverberant religious metaphor. In his convocation sermon of 1536, Latimer placed a distinctive gloss on the parable of good stewardship in Luke 16. The faithful steward was one 'that coineth no new money, but taketh it ready coined of the good man of the house; and neither changeth it, ne clippeth it'. Prelates and curates had failed this test, 'despising the money of the Lord, as copper and not current' they either 'coined new themselves, or else uttered abroad newly coined of other'. ${ }^{134}$ True religion, like the coin of the realm, invited the predatory attention of coiners and clippers. Latimer's subtlety contrasts with the crassness of a remark attributed to the conservative vicar of Ticehurst in Sussex, who, holding up a groat, said that people would not dare to spit upon the king's face on it, but they would spit upon an image, meaning 'thow spettes apon god'. 135

Clerical counterfeiting was not always metaphorical. In 1530 a priest was imprisoned at Rye for coin-clipping, and another was hanged in London for the same offence in July 1532, in a shocking break with precedent executed without first being degraded from his orders. ${ }^{136}$ Among those implicated in a coining operation in the Welsh Marches in 1534 were the vicar of Talgarth and a Cistercian of Strata Florida. Coining charges were also brought in 1534 against the bailiff of Norton Abbey (Cheshire), after the abbot had taken into his service a former employee of the Tower mint. ${ }^{137}$ In December 1536 a French priest was executed for counterfeiting the sign manual. ${ }^{138}$ Earlier that year, the commissioners sequestering valuables at Walsingham Priory made a remarkable discovery: 
a secrete privye place within the howse, where no channon nor annye other of the howse dyd ever enter, as they saye, in which there were instrewmentes, pottes, belowes, flyes of suche strange colers as the lick non of us had seene, with poysies, \& other thinges to sorte, \& denyd gould and sylver, nothing ther wantinge that should belong to the arte of multyplyeng. ${ }^{139}$

'Multiplication' was the alchemical attempt to transmute base into precious metal. ${ }^{140}$ Here in a secret laboratory of dissimulation, monks were gnawing at the financial sinews of the state, just as the shrine's feigned relics sought to sap its spiritual fibre. Connections between secular and religious concerns about forgery may be ultimately impalpable. Yet in their confluence it is tempting to detect a paradigm in motion, a shift in the direction of that amplifed polarity of truth and falsehood, essence and inverse, which we have been taught to recognise as the bedrock of early modern intellectual systems. ${ }^{141}$ The regime of Henry VIII (whose father had come to the throne with the flimsiest and least convincing of hereditary claims) placed a distinct premium on authenticity. ${ }^{142}$

The Henrician assault on traditional religious culture has been well covered in recent scholarship, particularly in Eamon Duffy’s justly-celebrated book The Stripping of the Altars. ${ }^{143}$ But the tendency in some revisionist writing to focus almost exclusively on the experience of dispossessed local communities can make it difficult to understand the motivation behind the campaigns, and the levels of elite support they were undoubtedly able to command. In directing attention away from the stripped and towards the strippers, I have hoped to recover some of the dynamics and momentum of the reforming process itself. It is not the intention of this essay to resurrect the 
thesis that the Henrician Reformation possessed an essentially 'Erasmian’ character, or indeed to propose the existence of any stable ideological core around which the religious policies of Henry VIII’s government revolved. ${ }^{144}$ Rather, I have attempted to account for the powerful instrumentality of manifestly radical change in a profoundly unstable religious landscape. Erasmian (and pre-Erasmian) tropes about deceptions practised by the clergy had a longstanding tenancy among educated lay elites; they were ideas singularly susceptible to appropriation and adaptation by coteries with distinct agendas; and once licensed by the crown, they exercised a highly destructive effect on important areas of late medieval English religious culture. The exposure of 'forgery' not only functioned as a powerful metaphor or discourse, which gave some favour of coherence to the faction-ridden religious politics of the Henrician state, but it was a line of attack which pressed unerringly on the weakest points of traditional religion, where conservatives could hardly begin to mount a convincing defence. It was a representational strategy which harnessed idealism to opportunism, fusing evangelical fervour and Erasmian rigour in ways that helped to rehabilitate the former and radicalise the latter. It had great inflationary potential, seeping from its precise limits to infuse a broader discourse of 'reform' and underwrite a more wholesale condemnation of traditional religion as 'superstition' and 'hypocrisy' - not least because of its ability to resonate with broader concerns about forgery and verification in the governance of the realm. It was also a vital legacy to the Protestant successor regimes. In the first year of Edward's reign, 'artificial figures which moved their heads, arms and legs' were again displayed at Paul's Cross, official homilies denounced the 'papistical leven of mans feyned religion', and royal injunctions ordered the utter extinction of shrines, tables, pictures, paintings 'and all other monuments of feigned miracles'. ${ }^{145}$ Under Elizabeth and 
James, the association of Catholicism with 'false miracles' became a staple ingredient of Protestant polemical writing. ${ }^{146}$ In its origins, this linkage was in large measure a defensive strategy, formulated to counter the temerity of those who subjected the king's proceedings to the discernment of visionary charisma. Yet its corrosive capacity resided finally in a simple fact of experience. For as Thomas More had conceded, 'alwaye it renneth in mennys myndys that myracles may be fayned'. ${ }^{147}$ 
* Earlier versions of this paper were given over the course of 2001-2 at the Sixteenth Century Studies Conference in Denver, Colorado, the Reformation Studies Colloquium at the University of Exeter, and seminars at the Universities of Birmingham and St Andrews. I learned much from participants on all these occasions, and particularly wish to thank Bernard Capp, Eamon Duffy, Brad Gregory, Andrew Pettegree, Richard Rex, Robert Swanson and Alexandra Walsham.

1 Thomas Cranmer, Miscellaneous Writings and Letters, ed. John Edmund Cox (Parker Society, Cambridge [hereafter PS], 1846), 460-1.

2 Jasper Ridley, Thomas Cranmer (Oxford, 1962), 91; Alan Kreider, English Chantries: The Road to Dissolution (Cambridge, Mass., 1979), 105-6; Diarmaid MacCulloch, Thomas Cranmer: A Life (New Haven and London, 1996), 124.

3 There has been no sustained attention to this theme, though there are insights in Margaret Aston’s magisterial work on image-breaking: England's Iconoclasts: Laws against Images (Oxford, 1988), 235-6; Faith and Fire: Popular and Unpopular Religion, 1350-1600 (London, 1993), 263-4, 266-70.

4 The most important works here include Stuart Clark, Thinking with Demons: the Idea of Witchcraft in Early Modern Europe (Oxford, 1997); Raymond Gillespie, Devoted People: Belief and Religion in Early Modern Ireland (Manchester, 1997); Alexandra Walsham, Providence in Early Modern England (Oxford, 1999). Effective 
distillations of the theme are R. W. Scribner, 'Incombustible Luther: the Image of the Reformer in Early Modern Germany’, in Scribner, Popular Culture and Popular Movements in Reformation Germany (London, 1987); Philip M. Soergel, 'The Afterlives of Monstrous Infants in Reformation Germany', in Bruce Gordon and Peter Marshall (eds.), The Place of the Dead: Death and Remembrance in Late Medieval and Early Modern Europe (Cambridge, 2000).

5 Eamon Duffy, The Stripping of the Altars: Traditional Religion in England 1400-1580 (New Haven and London, 1992). Puzzlement about the apparent inability of local communities to resist reformist inroads into a thriving religious culture has been a notable by-product of the 'revisionist' surge in English Reformation studies. For a helpful summary of the issues, see Christopher Marsh, Popular Religion in Sixteenth-Century England (Basingstoke, 1998), ch. 5 'Conclusions: The Compliance Conundrum’.

$6 \quad$ See Richard Rex, 'The Execution of the Holy Maid of Kent', $\underline{\text { Historical }}$ $\underline{\text { Research, lxiv (1991); Diane Watt, Secretaries of God: Women Prophets in Late }}$ Medieval and Early Modern England (Cambridge, 1997), ch. 3; Watt, 'Reconstructing the Word: The Political Prophecies of Elizabeth Barton (1506-1534), Renaissance Quarterly, i (1997); Ethan H. Shagan, 'Print, Orality and Communications in the Maid of Kent Affair’, Journal of Ecclesiastical History, lii (2001); Shagan, ‘Popular Politics and the English Reformation, c. 1525-1553’ (Princeton Univ, PhD thesis, 2000), ch. 2. Collectively, these works supersede the overly hagiographical account in Alan Neame, The Holy Maid of Kent. The Life of Elizabeth Barton 1506-1534 (London, 1971). 
'The Sermon against the Holy Maid of Kent and her Adherents, delivered at Paul's Cross, November the 23rd, 1533, and at Canterbury, December the 7th', ed. L. E. Whatmore, English Historical Review, lviii (1943); Statutes of the Realm, ed. A. Luders et al. (London, 1810-1828), iii, 446-51 (25 Henry VIII, c. 12).

8 'Sermon against the Holy Maid', 469-70, 471, 473-4; Statutes, iii, 448, 450.

$9 \quad$ Statutes, iii, 447; 'Sermon against the Holy Maid', 475. For the suggestion that the attainder may have been printed for public consumption, see G. R. Elton, Policy and Police: The Enforcement of the Reformation in the Age of Thomas Cromwell (Cambridge, 1972), 210n.

10

The rector of Aldington, Richard Master, was said to have encouraged pilgrimage to the Court-at-Street chapel 'for hys own lucre and advauntage': $\underline{\text { Statutes, }}$ iii, 447.

11 For discussion of earlier prophetic 'holy women', see Rosalynn Voaden (ed.), Prophets Abroad: The Reception of Continental Holy Women in Late-Medieval England (Cambridge, 1996); Caroline Walker Bynum, Holy Feast and Holy Fast: The Religious Significance of Food to Medieval Women (Berkeley, 1987); Shagan, 'Popular Politics', 134-6. 65-6; Richard Morison, Apomaxis Calumniarum (London, 1537, STC 18109), fos. 
$71^{\mathrm{r}}-74^{\mathrm{r}}$; The Itinerary of John Leland, ed. Lucy Toulmin Smith, 5 vols. (London, 1964), iv, 66; John Bale, A Mysterye of Inyquyte contayned within the Heretycall Genealogye of Ponce Pantolabus (Geneva [ie Antwerp], 1545, STC 1303), fo. 30; Henry Brinkelow, Complaynt of Roderyck Mors and The Lamentacyon of a Christen Agaynst the Cyte of London, ed. J. M. Cowper (Early English Text Soc. [hereafter EETS], extra ser. xxii, London, 1874), 82; Edward Hall, Chronicle, ed. H. Ellis (London, 1809), 803-23; William Lambarde, A Perambulation of Kent (London, 1576, STC 15175), 149-52.

13 William Tyndale, An Answer to Sir Thomas More’s Dialogue, ed. Henry Walter, (PS, 1850), 89-91; Greg Walker, Persuasive Fictions: Faction, Faith and Political Culture in the Reign of Henry VIII (Aldershot, 1996), 148; The Work of John Frith, ed. N. T. Wright (Oxford, 1978), 419; Robert Barnes, A Supplication Made... unto the most Excellent and Redoubted Prince King Henry the Eyght (London, 1531, STC 1470), fo. $138^{\mathrm{v}}$. For the miraculous cure of Anne Wentworth, the 'Maid of Ipswich', at the chapel of Our Lady there in 1516, see Diarmaid MacCulloch, Suffolk and the Tudors (Oxford, 1986), 143-6. reading papist miracle-claims, both current and historical: William Tyndale, Doctrinal Treatises and Introductions to Different Portions of the Holy Scriptures, ed. Henry Walter (PS, 1848), 195, 232-5, 286-7; Tyndale, Answer to More, 103, 129; Frith, Work, 413; George Joye (?), The Souper of the Lorde, in Thomas More, The Answer to a Poisoned Book, ed. Stephen Merriam Foley and Clarence H. Miller (New Haven and London, 1985), 335, 339-40; (Heinrich Bullinger), A Commentary upon the 
Seconde Epistle of S. Paul to the Thessalonians, tr. R. H. (Southwark, 1538, STC 4054), esp. fos. $48^{\mathrm{v}}$ ff; John Bale, The Epistle Exhortatorye of an Englyshe Christyane

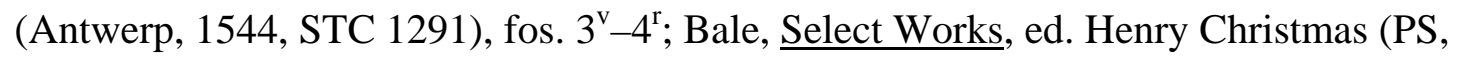
1849), 233; John Hooper, Early Writings, ed. Samuel Carr (PS, 1843), 532; Hooper, Later Writings, ed. Charles Nevinson (PS, 1852), 45; 'Confutation of Unwritten Verities', 45-8. See also the correspondent of Cromwell's who professed scepticism about Barton’s revelations, 'for I have lernyd the gospell, Attendite a falsis prophetis': British Library (hereafter BL), Cotton MS Cleo. E. iv, fo. $87^{\mathrm{r}}$ (Three Chapters of Letters relating to the Suppression of Monasteries, ed. Thomas Wright, Camden Soc. [hereafter CS], xxvi (1843) [hereafter SL], 14).

15

Tyndale, Doctrinal Treatises, 286, 325; Tyndale, Expositions and Notes... together with The Practice of Prelates, ed. Henry Walter (PS, 1849), 268, 293. See also William Roy and Jerome Barlow, The Burial of the Mass, in Edward Arber (ed.), English Reprints (London, 1871), 63, 73, 94-5, 106-7, which alternates between presenting miracles as clerical inventions and as 'the devils arte'.

16 Thomas More, A Dialogue Concerning Heresies, ed. Thomas M. C. Lawler et al (New Haven and London, 1981), 61-2, 71-5. al (New Haven and London, 1973), 243-6, 253, 274-8. faynnynge / no possybylyte of counterfettynge'. See also his Supplication of Souls, 
ed. Frank Manley et al (New Haven and London, 1990), 197, where it is alleged that God preserves the merit of faith by ensuring that 'apparycyons / reuelacyons / and myracles / shold not be to copyouse and commune'.

See Richard Marius, Thomas More: A Biography (London, 1984), 446-53.

20

Thomas More, Translations of Lucian, ed. Craig R. Thompson, (New Haven and London, 1974), 5-7. In response to a request from Albert of Brandenburg to write some saints' lives in 1517, Erasmus observed that they were typically 'old wives tales... no educated or serious-minded person can read them without disgust': The

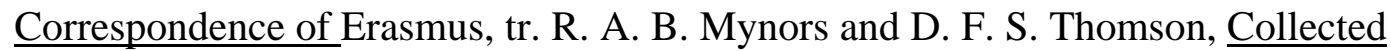

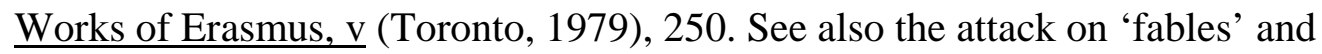
'ridiculous tales of miracles' in his The Edition of St Jerome, ed. and tr. James F. Brady and John C. Olin, Collected Works, lxi (Toronto, 1992), 19-24. London, 1986), 285-9.

22

The charlatan unmasked himself when Duke Humphrey of Gloucester ascertained that despite claiming to have been blind since birth, he could identify and name colours: More, Dialogue, 85-6. The incident reappears in Tyndale’s Practice of Prelates, 297-8, where it is insinuated that the clergy conspired to murder Gloucester because of his talent to 'spy false miracles'. It eventually found its way into Shakespeare (2 Henry VI, II,i, 62-165). 
More, Dialogue, 88. A contemporary account is Johan Vetter, De quattor heresiarchis ordinis Praedicatorum (Nuremberg, 1509). Erasmus rehearsed the events again in the colloquy Exequiae Seraphicae of 1531: The Colloquies of Erasmus, ed. Craig R. Thompson (Chicago and London, 1965), 502. a parallel with a miracle claimed by the Maid of Kent. When Henry was at mass in the Church of Our Lady in Calais in October 1532, an angel lifted the host from the hands of the priest, and delivered it to Barton, who had been invisibly transported there: BL, Cotton MS Cleo. E. iv, fo. $87^{\vee}$ ( $\underline{\text { LL, }}$ 15); Statutes, iii, 448. For enlightening discussion of the eucharist as 'holy food' in the lives of female saints, see Bynum, $\underline{\text { Holy Feast }}$ and Holy Fast.

More, Dialogue, 239, 88-9.

Decrees of the Ecumenical Councils, ed. Norman P. Tanner, 2 vols. (London, 1990), i, 263. See Colin Morris, ‘A Criticism of Popular Religion: Guibert of Nogent on The Relics of the Saints', in G. J. Cuming and Derek Baker (eds.), Popular Belief and Practice (Studies in Church History, viii, Cambridge, 1972); Jonathan Sumption, Pilgrimage: an Image of Medieval Religion (London, 1975), 35-41. 1966), 27. 
Giovanni Boccacio, The Decameron, tr. G. H. McWilliam (Harmondsworth, 1972), 507, 512.

The Riverside Chaucer, ed. Larry D. Benson, 3rd edn (Oxford, 1988), 194-5.

Circulating in England on the Eve of the Reformation (Hartford, Conn., 1965), 7;

John A. F. Thomson, The Early Tudor Church and Society (London, 1993), 94. For earlier attacks on unauthorised pardoners, see Wendy Scase, Piers Plowman and the New Anticlericalism (Cambridge, 1989), 142-3.

John Heywood, The Play Called The Four PP, in Medieval and Tudor Drama, ed. John Gassner (New York, 1963), 245-6; The Pardoner and the Frere, in English Miracle Plays, Moralities and Interludes, ed. Alfred W. Pollard, 8th edn (Oxford, 1927), 117-18. See also Cock Lorell’s Bote: A Satirical Poem, ed. E. F. Rimbault (London, Percy Society, 1843), 4-8, and a similarly rumbustious Scottish treatment of the theme in Sir David Lindsay, Ane Satyre of the Thrie Estatis (EETS, original ser., xxxvii, London, 1869), 453-62.

32 More, Dialogue, 98. More answers the objection by suggesting that apparent duplication of relics may in fact be caused by partition of the body, the coincidence of saints with similar names, or the veneration of genuine relics of saints 'unknowen and mysnamed': ibid., 221-2. 
Erasmus, Colloquies, 288-289, 293-7, 301. For incisive remarks on the theological and cultural difficulties presented by relics of the Virgin's milk, see Nicholas Vincent, The Holy Blood: King Henry III and the Westminster Blood Relic (Cambridge, 2001), 41-2.

The Works of a Lollard Preacher, ed. Anne Hudson (EETS, original ser., cccxvii, London, 2001), 231; Anne Hudson, The Premature Reformation: Wycliffite Texts and Lollard History (Oxford, 1988), 305.

Ibid.; Tyndale, Doctrinal Treatises, 336; Answer to More, 129, 135. O’Donnell (EETS, original ser., cclxxxii, London, 1981), 115-17. For the question of Tyndale’s involvement, see David Daniell, William Tyndale: A Biography (New Haven and London, 1994), 70-4. Note here an orthodox medieval tradition applying apocalyptic warnings about false prophets to the coming of the friars: Penn R. Szittya, The Antifraternal Tradition in Medieval Literature (Princeton, 1986), 211-12, 226. mandate had been anticipated by a proposal for legislation in the 1531 parliament (probably the work of Christopher St German) banning any publicity for miracles until they had been investigated by the Church: Aston, England’s Iconoclasts, 215; J. 
A. Guy, The Public Career of Sir Thomas More (New Haven and London, 1980), $151-2$.

39

Geoffrey Baskerville, English Monks and the Suppression of the Monasteries (London, 1937), 22-4, 228-9; David Knowles, The Religious Orders in England: III The Tudor Age (Cambridge, 1959), 287-8; G. W. O. Woodward, The Dissolution of the Monasteries (London, 1966), 51-4. There is a more considered treatment of the issue in G. W. Bernard, 'Vitality and Vulnerability in the Late Medieval Church: Pilgrimage on the Eve of the Break with Rome', in John L. Watts (ed.), The End of the Middle Ages? England in the Fifteenth and Sixteenth Centuries (Stroud, 1998).

40 Knowles, Religious Orders, 270-3. Layton and Legh were products of humanist Cambridge.

41 Public Record Office, London (hereafter PRO), SP 1/95, fos. 38 ${ }^{\mathrm{r}} \mathrm{C}^{\mathrm{v}}$ (Letters and Papers, Foreign and Domestic, of the Reign of Henry VIII, ed. J. S. Brewer et al, 21 vols. (London, 1862-1932) [hereafter LP], ix, 42).

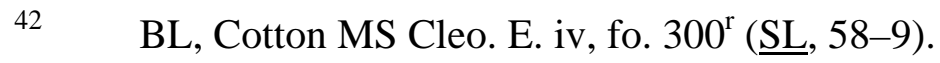

43 BL, Cotton MS Cleo. E. iv, fo. $145^{\mathrm{r}}$ ( $\left.\underline{\mathrm{SL}}, 85\right)$.

44 PRO, SP $1 / 102$, fos. $85^{\mathrm{r}}-104^{\mathrm{r}}$ (quotes at $101^{\mathrm{v}}, 103^{\mathrm{v}}$ : 'hic multa apparuit superstitio in fictes reliquiis \& miraclis', 'vane relique et ficte') (LP, x, 364). 
45 Charles Wriothesley, A Chronicle of England, ed. William Douglas Hamilton, 2 vols., CS, new ser., xi, xx (1875-77), i, 31.

46

BL, Harleian MS 791, fos. $27^{\mathrm{r}}-28^{\mathrm{r}}$. See Erasmus, Pilgrimages to Saint Mary of Walsingham and Saint Thomas of Canterbury, ed. and tr. J. G. Nichols (London, 1875), 209-12; Henry de Vocht (ed.), The Earliest English Translations of Erasmus’ Colloquia (Louvain, 1928), l-lv; Erasmus, Colloquies, 293, 296.

47 PRO, SP 6/1, fos. $123^{\mathrm{r}}-127^{\mathrm{r}}$. Both G. R. Elton and Stanford Lehmberg regarded this as a 'private’ bill, unconnected with Cromwell's secretariat: Elton, 'Parliamentary Drafts 1529-1540’, in his Studies in Tudor and Stuart Politics and Government Vol. II (Cambridge, 1974), 71; Lehmberg, The Reformation Parliament, 1529-1536 (Cambridge, 1970), 224. The draft's heavy dependence on the phraseology of the monastic injunctions and findings of the visitors, however, make it less evident that this was the case. I am indebted to Anthony Shaw for discussion of this point.

48

Hugh Latimer, Sermons, ed. George Elwes Corrie, 2 vols. (PS, 1844-5), i, 5355.

49 Visitation Articles and Injunctions of the Period of the Reformation, ed.

Walter Howard Frere and William McClure Kennedy, 3 vols. (London, 1910), ii, 5-6.

50 A dialogue or communication of two persons, devysed and set forthe in the laten tonge by the noble and famose clarke Desiderius Erasmus intituled ye 
pylgremage of pure devotyon (London, ?1537, STC 10454). The STC date of 1540 is

followed by J. K. McConica, English Humanists and Reformation Politics under

Henry VIII and Edward VI (Oxford, 1965), 189-90, but see Aston, England's

Iconoclasts, 197-8; de Vocht, Earliest English Translations, xliv-li, For Thomas

Cromwell's regard for Erasmus, see G. R. Elton, Reform and Renewal. Thomas

Cromwell and the Common Weal (Cambridge, 1973), 31-2.

51 A dialogue or communication, fos. $3^{\mathrm{r}}-4^{\mathrm{v}}$,

52 Ibid., sig. B6 ${ }^{\mathrm{r}}$; Erasmus, Opera omnia (Amsterdam, 1969- ), i (3), 478.

Thompson gives 'many such affairs are contrived for profit': Colloquies, 295. For further examples of evangelical colonisation of Erasmian tropes, particularly in the course of translation, see J. K. Yost, 'German Protestant Humanism and the Early English Reformation: Richard Taverner and Official Translation’, Bibliothèque d'humanisme et renaissance, xxxii (1970);Yost, ‘Taverner's Use of Erasmus and the Protestantization of English Humanism’, Renaissance Quarterly, xxiii (1970); Peter Marshall, 'Mumpsimus and Sumpsimus: The Intellectual Origins of a Henrician Bon Mot', Journal of Ecclesiastical History, lii (2001).

$53 \quad$ PRO, SP 1/129, fo. $12^{\mathrm{r}}$ ( $\underline{\mathrm{LP}}$, xiii (1), 231); LP, xiii (1), 348.

54 Wriothesley, Chronicle, i, 74-6.

55 Original Letters relative to the English Reformation, ed. Hastings Robinson, 2 vols. (PS, 1846-7), ii, 604, 606, 609. 
Canterbury', in Narratives of the Days of the Reformation, ed. John Gough Nichols, CS, Ixxvii (1859), 286.

57

Wriothesley, Chronicle, i, 75-6. This was an old Lollard accusation: Hudson, Premature Reformation, 304n.

58 PRO, SP 1/138, 49 (Latimer, Sermons, ii, 407-8). Wriothesely, Chronicle, i, 90.

60 See Peter Marshall, 'The Rood of Boxley, the Blood of Hailes and the Defence of the Henrician Church', Journal of Ecclesiastical History, xlvi (1995). 719 for London's suggestion of chicanery with an image by the Crutched Friars of Tellisford, Somerset. 
65

BL, Cotton MS Cleo. E. iv, fos. $267^{r}, 268^{r}, 264^{r}$ (SL, 221-25).

66

BL, Cotton MS Cleo. E. iv, fo. 265 ${ }^{\mathrm{r}}$ (ㄴ, 225-7).

67

68

BL, Egerton MS 2603, fo. $26^{\mathrm{r}}$ (LP, xiv (1), 69).

BL, Cotton MS Cleo. E. iv, fo. $240^{\mathrm{v}}$ (SL, 234).

69

Denis Bethell, ‘The Making of a Twelfth-Century Relic Collection’, in Cuming and Baker (eds.), Popular Belief and Practice, 61; Ronald C. Finucane, Miracles and Pilgrims: Popular Beliefs in Medieval England (London, 1977), ch. 11. See also André Vauchez, Sainthood in the Later Middle Ages, tr. Jean Birrell (Cambridge, 1997), 444-53 for the argument that in the fourteenth-fifteenth centuries miraculous cures effected by saints were increasingly associated with images and did not involve direct contact with the relics. The English visitors regularly noted the demand for the girdles of female saints from women in labour, though these may often have been belts engirdling an image of the saint, a suggestion I owe to Robert Swanson.

70

SL, 218-19: the commissioners' judgement in Sep. 1538 on the collections in the Winchester monasteries of Hide and St Mary. 
72 Wriothesley, Chronicle, i, 86-7. Whether or not the bones were actually burned is an enduring historical mystery: see John Butler, The Quest for Becket’s Bones (New Haven and London, 1995).

(New Haven and London, 1964-9), i, 276.

74

Tyndale Answer to More, 129, 135; Knowles, Religious Orders, 488. At the same time that England's patron saint was being vilified, Bishop Barlow was arguing that the accounts of David patron of Wales were 'so uncerten of trueth, and certenly ful of lyes that not only his sayntly holynesse ys to be suspected, but rather to be dowted whether any soch person was ever bisshop there’: BL, Cotton MS Cleo. E. iv, fo. $316^{\mathrm{v}}$ ( $\left.\underline{\mathrm{SL}}, 208\right)$.

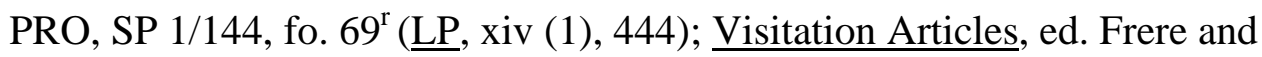
Kennedy, ii,109n.

Ibid, 38-9.

77 Ibid., 59-60. At around the same time, Mathew Parker was preaching in Suffolk that Christians should not put their trust in 'men's bones and coats, whereof we have no certainty whether they were the relics of saints or no': Correspondence of Matthew Parker, ed. John Bruce (PS, 1853), 7. 
Wilfrid Holme, The Fall and Evill Successe of Rebellion (London, 1572, STC 13602), sigs. $E 1^{\mathrm{v}}, \mathrm{G} 3^{\mathrm{v}}-4^{\mathrm{r}}$. On Holme, see A. G. Dickens, Lollards and Protestants in the Diocese of York (Oxford, 1959), 114-31.

Lordes Temple (London, 1538, STC 26063), sigs. E3 ${ }^{\mathrm{v}}-4^{\mathrm{r}}$, F8 ${ }^{\mathrm{v}}-\mathrm{G} 1^{\mathrm{r}}$. Cf Erasmus, Colloquies, 293. For a similar itemising of the images, relics and roods which had been created 'for lucre sake', see Lancelot Ridley, A Commentary in Englyshe upon Sayncte Paules Epystle to the Ephesyans (London, 1540, STC 21038.5), sigs. A6 $6^{\mathrm{V}}-7^{\mathrm{r}}$. v, 404-9. See E. W. Dormer, Gray of Reading: A Sixteenth-Century Controversialist and Ballad-Writer (Reading, 1923). The official status of the text can be ascertained from the fact that two of its stanzas were composed to be fixed on the gallows of the Observant friar John Forest in May 1538: Foxe, Acts and Monuments, v, 180. See Peter Marshall, 'Papist as Heretic: the Burning of John Forest 1538', Historical Journal, xli (1998).

82 See Butler, Quest for Becket’s Bones, 119-20; Elton, Policy and Police, 1958, which identifies the hand as that of Thomas Derby, clerk to the Privy Council. It appears to have been prompted by the promulgation of the papal excommunication of Henry in December 1538, which itself was precipitated by the king's sacrilegious handling of Thomas Becket's relics. 
PRO, SP $1 / 143$, fos. $203^{\mathrm{r}}-205^{\mathrm{r}}$ (LP, xiv (1), 402). The comic revelation about Our Lady of Worcester acquires an edge from the attempt of a townsman in 1537 to revive devotion to the image, claiming the ending of pilgrimage had decayed 'the lucre and profett of this towne', and arguing 'though our Ladyes cotte and her yoelles [jewels] be taken awaye from her, the symylytude of this is no worse to pray unto': PRO, SP 1/124, fo. $111^{\mathrm{r}}$ (LP, xii (2), 587). PRO, SP 1/139, fo. $164^{\mathrm{v}}$ (LP, xiii (2), 880).

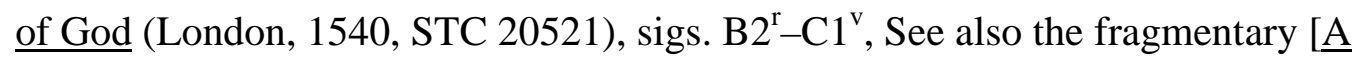
panegyric of Henry VIII as the abolisher of papist abuses] (London, not after 1537, STC 13089a).

William Thomas, The Pilgrim: A Dialogue on the Life and Actions of King Henry VIII, ed. J. A. Froude (London, 1861), 9-12, 36-44. For further examples of expatriate Englishmen defending the king as a reformer of the abuses of shrines and monasteries, see Peter Marshall, 'The Other Black Legend: The Henrician Reformation and the Spanish People’, English Historical Review, cxvi (2001). 
(Aldershot, 1999). Wriothesley’s, Geoffrey Gibbons, The Political Career of Thomas Wriothesley, First Earl of Southampton (Lampeter, 2001), 271-82. 1533, however, Elyot had lamented ‘miracles reproved for jougglynes’ by the German reformers: cited in Greg Walker, 'Dialogue, Resistance and Accomodation: Conservative Literary Responses to the Henrician Reformation', in N. Scott Amos, Andrew Pettegree and Henk van Nierop (eds.), The Education of a Christian Society: Humanism and Reformation in Britain and the Netherlands (Aldershot, 1999), 91. 79-82, though the observation (p. 81) that Lazenby 'seems to a modern eye to display a pathetically superstitious and subnormal intelligence' may have more to say about the scholarship of the 1950s than the religion of the 1530s. 

1971), 125. The colloquy Exorcismus, sive Spectrum revolves around a faked apparition: $\underline{\text { Colloquies, } 230-7 .}$

102 BL, Harleian MS 425, fos. 4-7. For the growing official coldness to the doctrine of purgatory in these years, see Peter Marshall, Beliefs and the Dead in Reformation England (Oxford, 2002), ch. 2. xiii (2), 62). The re-igniting candle was an established hagiographical motif, one of the miracles associated with St Peter Martyr: Jacob de Voragine, The Golden Legend, tr. William Granger Ryan, 2 vols. (Princeton, 1993), i, 264. 
106 London Chronicle during the reigns of Henry the Seventh and Henry the

Eighth, ed. Clarence Hopper, in Camden Miscellany vol. 4, CS, lxxiii (1859), 13. See also John Stow, The Chronicles of England from Brut unto the Present Year (Newbury, 1580), 1013; Susan Brigden, London and the Reformation (Oxford, 1989), $290-1$.

107 PRO, SP $1 / 137$, fo. $188^{\mathrm{r}}$ (LP, xiii $\left.(2), 596\right)$. On the potency of rumour in the 1530s, see Ethan H. Shagan, 'Rumours and Popular Politics in the Reign of Henry VIII', in Tim Harris (ed.), The Politics of the Excluded, c. 1500-1850 (Basingstoke, 2001).

108 PRO, SP 1/141, fo. $147^{\mathrm{r}}$ (LP, xiii (2), 1243); SP 1/133, fo. $59^{\mathrm{r}}$ ( $\underline{\mathrm{LP}}$, xiii (1), 1199); SP 1/151, fo. $173^{\mathrm{r}}$ (LP, xiv (1), 1052).

109 A classic statement of this idea is Norman Cohn, The Pursuit of the Millenium: Revolutionary Millenarians and Mystical Anarchists of the Middle Ages (London, 1957). For a parallel recourse to political prophecies by Henry VIII’s opponents, see Elton, Policy and Police, ch. 2; Sharon L. Jansen, Political Protest and Prophecy under Henry VIII (Woodbridge, 1991).

110 Documents Illustrative of English Church History, ed. Henry Gee and W. J. Hardy (London, 1896), 187. Lorenzo Valla’s De falso credita et ementita Constantini 
donatione declamatio (1440), which exposed the 'donation' as an eighth-century forgery, was published in 1534 in an English translation (possibly by William Marshall): $\underline{\text { A Treatyse of the Donation or Gyfte and Endowment of Possessyons, }}$ given and granted unto Sylvester Pope of Rome by Constantyne Emperour of Rome (London, 1534, STC 10454). The conservative Stephen Gardiner was equally ready to throw the donation in the face of papalist opponents: Lucy E. C. Wooding, Rethinking Catholicism in Reformation England (Oxford, 2000), 60.

111 See Hall, Chronicle, 823 for the claim that the heavy rain which prevented the rebel army crossing the river Don during the Pilgrimage of Grace was 'a great miracle of God'. Marian London supplies an intriguing case of a Protestant 'forged miracle': a young woman induced to denounce religious policy as a disembodied voice from within a wall in Aldersgate Street. Chronicle of the Grey Friars of London, ed. John Gough Nichols , CS, liii (1852), 90; The Diary of Henry Machyn, ed. John Gough Nichols, CS, xlii (1847), 66. For the subsuming of later Protestant readings of the miraculous into the theory of providentialism, see the superb treatment in Walsham, Providence.

112 An isolated example of a 'pro-regime' vision ended with its recipient in the Tower and on the wrack. For the, admittedly murky, circumstances, see BL, Cotton MS Calig. B. i, fo. 130 (LP, xii (2), 80); Elton, Policy and Police, 58-9, 384.

113 Duffy, Stripping of the Altars, 8; Tyndale, Doctrinal Treatises, 302. See also Tyndale, Expositions and Notes, 287, 162; Frith, Work, 141; Latimer, Sermons, i, 50; 
George Joye, The Subversion of Moris false foundacion (Emden, 1534, STC 14829), fo. $3^{\mathrm{v}}$.

114 Tyndale, Doctrinal Treatises, 438; Becon, Early Works, 134-5, 241; Roy and Barlow, Burial of the Mass, 131.

115 Tyndale, Answer to More, 22, 103.

116 PRO, SP 1/191, fo. 95 (LP, viii, 407); LP, xviii (2), 546 (p. 315); xi, 1424.

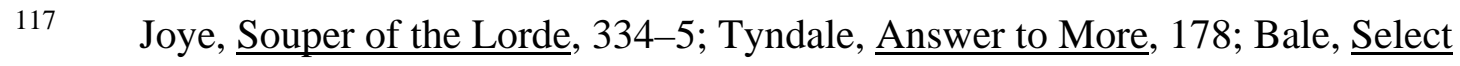
Works, 233; Hooper Early Writings, 164-5; Roy and Barlow, Burial of the Mass, 63. The 'feynid miracle of the sacrament of bred' was an earlier Lollard trope: Ann Eljenholm Nichols, Seeable Signs: The Iconography of the Seven Sacraments 13501544 (Woodbridge, 1994), 92.

118 See Miri Rubin, Corpus Christi: The Eucharist in Late Medieval Culture (Cambridge, 1991), 112-29; Duffy, Stripping of the Altars, 102-9; Nichols, Seeable Signs, 51n, 247, 256.

119 Wriothesley, Chronicle, i, 152. See also Chronicle of the Grey Friars, ed. Nichols, 48; 'Confutation of Unwritten Verities’, 66.

120 Gilbert Burnet, The History of the Reformation of the Church of England, ed. N. Pocock, 7 vols. (Oxford, 1865), iv, 259, 261. We can note here references to 
'pretensed religion' and 'simulate povertie' in the relics bill of 1536 (PRO, SP 6/1, fo. $\left.126^{\vee}\right)$. See also Elton, Policy and Police, 195 for a pamphlet drafted within Cromwell's circle in 1539-40 condemning 'merciless monks, false friars... and other fools of feigned religion’.

121 Paul Ayris, 'Preaching the Last Crusade: Thomas Cranmer and the "Devotion” Money of 1543’, Journal of Ecclesiastical History, xlix (1998), 699. Cf Bishop Barlow’s condemnation of ‘fayned indugences’ in 1538: BL, Cotton MS Cleo. E. iv, fo. $316^{\mathrm{v}}$ ( $\left.\underline{\mathrm{SL}}, 208\right)$.

122 Tudor Royal Proclamations, ed. Hughes and Larkin, i, 302.

123 See Aston, England's Iconoclasts, 401-8; Maurice Howard and Nigel Llewellyn, 'Painting and Imagery', in Boris Ford (ed.), The Cambridge Guide to the Arts in Britain: Vol. 3 Renaissance and Reformation (Cambridge, 1989), 237-8.

124 Statutes, iii, 327, 330 (22 Hen. VIII, cc. 10, 12). Paul Slack has commented on the tendency in Tudor vagrancy legislation to demonise formerly tolerated itinerant entertainers. 'It is as if social boundaries were being redrawn and proper, repectable society being newly and more tightly defined': Poverty and Policy in Tudor and Stuart England (London, 1988), 24. \& 35 Hen. VIII, c. 6). These measures were a mixture of government and privatelysponsored bills: Elton, Reform and Renewal, 109-10. 
Some of the same language, in a less concentrated burst, appears in economic measures enacted in Henry VII's parliaments, though not, interestingly, in the

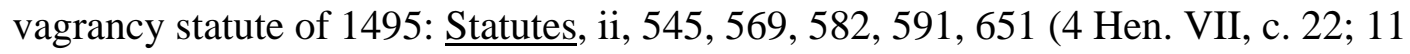
Hen. VII, cc. 2, 19, 27; 19 Hen. VII, c. 6).

127 Statutes, iii, 430 (24 Hen. VIII, c. 13).

128 Statutes, iii, 532 (27 Hen. VIII, c. 2); Chronicle of the Grey Friars, ed. Nichols, 44; Wriothesley, Chronicle, i, 60; Stow, Chronicles of England, 1013. Cromwell's memoranda suggest a more general measure against 'forging of false evidence’ was being considered at this time: $\underline{\text { LP, }}$ x, 254. Note that the 1536 Suppression Act accused abbots of having 'lately fraudulently and craftily made feoffments, estates, gifts, grants, and leases' under their convent seals, a 'fraud' firmly in the eye of the beholder, depriving the crown of spoils it expected to accrue: Documents, ed. Gee and Hardy, 261.

129

Statutes, iii, 502 (26 Hen. VIII, c. 6). Royal commissioners examined a string of suspected coiners at Bewdley and Shrewsbury in October 1534: PRO, SP 1/86, fos. $4^{\mathrm{r}}-10^{\mathrm{r}}$ (LP, vii, 1225). The activity of clippers in 1537 prompted consideration of 'a proclamation for false and clipped coin, and great punishment for possessors of false money’: LP, xii (2), 1122, 1151 (2), 1151 (3). 
130 It is ironic, though not necessarily paradoxical, that the regime itself was shortly to threaten the integrity of the coinage by experimenting with debased issues: C. E. Challis, The Tudor Coinage (Manchester, 1978), 82-95.

$131 \quad$ Bale, Select Works, 95.

132 More, Dialogue, 217-19. In view of the obsessive concern the Henrician regime would manifest through the 1530s with traitors within, this seems a particularly unfortunate analogy.

134 Latimer, $\underline{\text { Sermons, }} 36$.

135 PRO, SP 1/133, fo. $52^{\mathrm{r}}$ (LP, xiii (1), 1199).

136 Challis, Tudor Coinage, 276; Brigden, London and the Reformation, 213. Anne Boleyn was reported to have refused to intercede for him, saying there were too many priests in the country already: E. W. Ives, Anne Boleyn (Oxford, 1986), 194-5.

137 PRO, SP $1 / 86$, fos. $7^{\mathrm{v}}-8^{\mathrm{v}}$ (LP, vii, 1225); Glanmor Williams, Wales and the Reformation (Cardiff, 1997), 80; Challis, Tudor Coinage, 287. 

refer to coins failing to meet requisite standards of weight and fineness. See Tudor Royal Proclamations, ed. Hughes and Larkin, i, 145-7, 156-73.

140 This was banned by statute of Henry IV’s reign: 5 Hen. IV, c. 4. See Will H. L. Ogrinc, 'Western Society and Alchemy from 1200 to 1500', Journal of Medieval History, v (1980). For a shortlived and disastrous interest on the part of Henry VI, see Ralph A. Griffiths, The Reign of King Henry VI (London, 1981), 386.

141 See Stuart Clark, 'Inversion, Misrule and the Meaning of Witchcraft', Past and Present, lxxxvii (1980); Clark, Thinking with Demons. For sensitive applications of the model to later sixteenth- and seventeenth-century English religious culture, see Michael Hunter, ‘The Problem of “Atheism” in Early Modern England’, Trans. Royal Hist. Soc., $5^{\text {th }}$ ser., xxxv (1985); Peter Lake, 'Anti-Popery: the Structure of a Prejudice', in Richard Cust and Ann Hughes (eds.), Conflict in Early Stuart England (London, 1989).

142 See C. S. L. Davies, 'The Cromwellian Decade: Authority and Consent', Trans. Royal Hist. Soc., $6^{\text {th }}$ ser., vii (1997), 178 for insightful comments on the Henrician regime's consciousness of its own weakness.

143 Other notable contributions include Duffy, The Voices of Morebath: Reformation and Rebellion in an English Village (New Haven and London, 2001), ch. 5; J. J. Scarisbrick, The Reformation and the English People (Oxford, 1984), chs. 4-5; Robert Whiting, The Blind Devotion of the People: Popular Religion and the English 
$\underline{\text { Reformation (Cambridge, 1989); Andrew D. Brown, Popular Piety in Late Medieval }}$ England: The Diocese of Salisbury 1250-1550 (Oxford, 1995), ch. 10; Christopher Haigh, English Reformations: Religion, Politics, and Society under the Tudors (Oxford, 1993), chs. 7-9 (the last-mentioned somewhat more optimistic about the ability of parishes to circumvent the destructive impulses of Henrician policy).

144 For the 1530s as a fundamentally 'Erasmian polity’, see McConica English Humanists, ch. 6 . The case for the Henrician reforms possessing a high degree of consistency based on broadly humanist principles is also made by Wooding, Rethinking Catholicism, ch. 2; G. W. Bernard, 'The Making of Religious Policy, 1533-1546: Henry VIII and the Search for the Middle Way’, Historical Journal, xli (1998); Bernard, ‘The Piety of Henry VIII’ in Amos, Pettegree and van Nierop (eds.), Education of a Christian Society. For a salutary reminder that humanist learning was the common inheritance of Catholic and Protestant thinkers, and that Erasmus's legacy was a deeply contested one, see Richard Rex, 'The Role of English Humanists in the Reformation up to 1559', in ibid.

145 Calendar of Letters, Despatches, and State Papers, Relating to the Negotiations between England and Spain... 1547-49, ed. Martin A. S. Hume and Royall Tyler (London, 1912), 219-20l; Certain Sermons or Homilies (1547), ed. Ronald B. Bond (Toronto, 1987), 112; Visitation Articles, ed. Frere and Kennedy, ii, 126.

146 See Clifford Davidson, “"The Devil’s Guts”: Allegations of Superstition and Fraud in Religious Drama and Art during the Reformation', in Clifford Davidson and 
Ann Eljenholm Nichols (eds.), Iconoclasm vs. Art and Drama (Kalamazoo, 1989); Adam Fox, Oral and Literate Culture in England 1500-1700 (Oxford, 2000), 122, 176; Helen L. Parish, ““Then May the Deuyls of Hell Be Sayntes Also”: The Mediaeval Church in Sixteenth-Century England', Reformation, iv (1999); Parish, ‘“Impudent and Abhominable Fictions”: Rewriting Saints’ Lives in the English Reformation', Sixteenth Century Journal, xxxii (2001); Alexandra Walsham, ‘Miracles, Visions and the English Catholic Mission’ (a paper given at the Sixteenth Century Studies Conference, Denver, October 2002).

147 More, Dialogue, 240. 